\title{
BOOKS AND PAMPHLETS RECEIVED
}

Anastasi, Anne. Psychological Testing. $2 \mathrm{~d}$ ed. New York: Macmillan, 1961. pp. 657. $\$ 7.50$.

Auerbach, Aline B. How to Give Your Child a Good Start. Illustrations by Doug Anderson. New York: Child Study Association of America, 1961. pp. 31. 40 cents.

- Trends and Techniques in Parent Education: A Critical Review. New York: Child Study Association of America, 1961. pp. 37. 75 cents.

Becker, Ernest, Ph.D. Zen: A Rational Critique. New York: Norton, 1961. pp. 192. $\$ 4$.

Crow, Lester D., Ph.D., and Alice Crow, Ph.D. (Eds.). Readings in Child and Adolescent Psychology. New York: Longmans, Green and Co., 1961. pp. 592. $\$ 3.95$.

Crow, Lester D., Ph.D., Alice Crow, Ph.D., and Walter Murray, Ph.D. (Eds.). Teaching in the Elementary School: Readings in Principles and Methods. New York: Longmans, Green and Co., 1961. pp. 571. \$3.95.

Elliott, Mabel, Ph.D., and Francis E. Merrill, Ph.D. Social Disorganization. 4th ed. New York: Harper, 1961. pp. 795. \$8.50.

Farnsworth, Paul R. (Ed.), Olga McNemar and Quinn McNemar (Assoc. Eds.). Annual Review of Psychology, Vol. 12. Palo Alto, Calif.: Annual Reviews, 1961. pp. 533. $\$ 7$ U.S.A.; $\$ 7.50$ elsewhere.

Francis, Roy G. The Rhetoric Science: $A$ Methodological Discussion of the Two-byTwo Table. Minneapolis: University of Minnesota Press, 1961.pp. 183. \$4.75.

Freud, Sigmund. The Ego and the Id. Newly transl. from the German and edited by James Strachey. New York: Norton, 1961. pp. 88. \$3.75.

Hallman, Ralph J. Psychology of Literature: A Study of Alienation and Tragedy. New York: Philosophical Library, 1961. pp. 262. \$4.75.

Hammer, Emanuel F., Ph.D. Creativity: An Exploratory Investigation of Gifted $A d$ olescent Artists. New York: Random House, 1961. pp. 150. $\$ 1.25$.
Herzog, Elizabeth. Children of Working Mothers. Children's Bureau Publ. No. 382, 1960. Washington: U. S. Government Printing Office, 1960. pp. 38. 20 cents.

Lush, Brandon, M.D., M.R.C.P. (Ed.). Concepts of Medicine: $A$ Collection of Essays on Aspects of Medicine. New York: Pergamon Press, 1961. pp. 286. $\$ 8.50$.

Myers, F. W. H. Human Personality and Its Survival of Bodily Death. Edited by Susy Smith. New Hyde Park, New York: University Books, 1961. pp. 416. $\$ 10$.

Nunberg, Herman, M.D. Curiosity. (The Freud Anniversary Lecture Series, The New York Psychoanalytic Institute.) New York: International Universities Press, 1961. pp. 88. $\$ 3$.

Shipley, Thorne (Ed.). Classics in Psychology. New York: Philosophical Library, 1961. pp. 1342. $\$ 20$.

Silverman, Hirsch Lazaar, Ph.D. Psychology and Education: Selected Essays. New York: Philosophical Library, 1961. pp. 169. \$3.75.

Snyder, William U., Ph.D., and B. June Snyder, M.A. The Psychotherapy Relationship. New York: Macmillan, 1961. pp. 418. \$7.50.

Social Legislation Information Service. Federal Agencies Financing Research: Complete 1961 Guide to Government Grants and Contracts. Washington, D. C,: Social Legislation Information Service, 1961. pp. 26. \$1.

Ulett, George A., Ph.D., M.D., and D. Wells Goodrich, M.D. A Synopsis of Contemporary Psychiatry. 2d. ed. St. Louis: Mosby, 1960. pp. 309. $\$ 6.50$.

World Health Organization. The Undergraduate Teaching of Psychiatry and Mental Health Promotion: Ninth Report of the Expert Committee on Mental Health. WHO Techn. Rep. Ser. No. 208. Geneva: WHO, 1961. pp. 36. 30 cents. (Columbia University Press, International Documents Service, 2960 Broadway, New York 27.) 